\title{
Emergent Strategies in Interventional Cardiology
}

\author{
Jiro Aoki, Gastón A. Rodríguez-Granillo, and Patrick W. Serruys
}

Thoraxcenter, Erasmus Medical Center, Rotterdam, The Netherlands.

Despite the advances in the treatment of patients with coronary artery disease, sudden cardiac death is still unacceptably prevalent. Patients with ischemic heart disease usually require a combination of therapies (drugs and coronary intervention) and may continue to experience symptoms.

Recently, numerous percutaneous interventional treatments and diagnostic tools have been developed to diagnose the vulnerable plaque and to treat the large number of patients with myocardial ischemia. Ongoing research on the use of drug eluting stents, catheter based bypass graft (percutaneous approaches that use the adjacent venous circulation to bypass an obstructed artery and stentbased approach for ventricle to coronary artery bypass), therapeutic angiogenesis and myogenesis, and the catheter based devices to detect the plaque vulnerability and composition (lipid-rich atheromatous core, thin fibrous cap, and expansive vessel remodeling) may result in additional diagnostic and therapeutic options for patients with coronary artery disease.

Key words: Percutaneous coronary bypass. Angiogenesis. Myogenesis. Vulnerable plaque.

\section{Estrategias emergentes en cardiología intervencionista}

A pesar de los avances que se han efectuado en el tratamiento de los pacientes con enfermedad coronaria, los cuadros de muerte súbita por causa cardíaca tienen todavía una prevalencia inaceptable. Los pacientes con cardiopatía isquémica requieren habitualmente la combinación de distintas formas de tratamiento (fármacos e intervención coronaria), a pesar de lo cual pueden seguir presentando sintomatología.

Recientemente, se han desarrollado numerosas formas de tratamiento mediante intervención percutánea y distintas herramientas diagnósticas que permiten la detección de las placas vulnerables y el tratamiento del elevado número de pacientes que presentan isquemia miocárdica. La investigación actual respecto al uso de endoprótesis con capacidad de liberación de fármacos, bypass coronario efectuado con catéteres (abordajes percutáneos en los que se utiliza la circulación venosa adyacente para revascularizar la arteria obstruida, así como el abordaje mediante endoprótesis para la conexión entre el ventrículo y la arteria coronaria), los abordajes terapéuticos de angiogénesis y miogénesis, y las técnicas intracoronarias para la detección de la vulnerabilidad y la composición de las placas (placas ateromatosas con abundante core lipídico, cubierta fibrosa fina y remodelado positivo), puede facilitar opciones diagnósticas y terapéuticas adicionales en los pacientes con enfermedad coronaria.

Palabras clave: Bypass coronario percutáneo. Angiogénesis. Miogénesis. Placas vulnerables.

coronary stenting. However, use of drug eluting stents, such as sirolimus eluting stents (Cypher) and paclitaxel eluting stents (TAXUS), are associated with markedly reduced restenosis rates in several randomized trials and registries. ${ }^{1-4}$ Drug eluting stents are now used in a majority of intracoronary stenting procedures. Nevertheless, in-stent restenosis still occurrs in some patients and some specific problems, such as late thrombosis after discontinuation of antiplatelet therapy has been reported..$^{5}$

Recently, other approaches to treat the coronary artery disease have been introduced. Percutaneous ap-

Correspondence: P.W. Serruys MD, PhD.

Thoraxcenter, Bd 406. Erasmus MC, Dr Molewaterplein 40. 3015 GD

Rotterdam. Países Bajos.

E-mail: p.w.j.c.serruys@erasmusmc.nl 


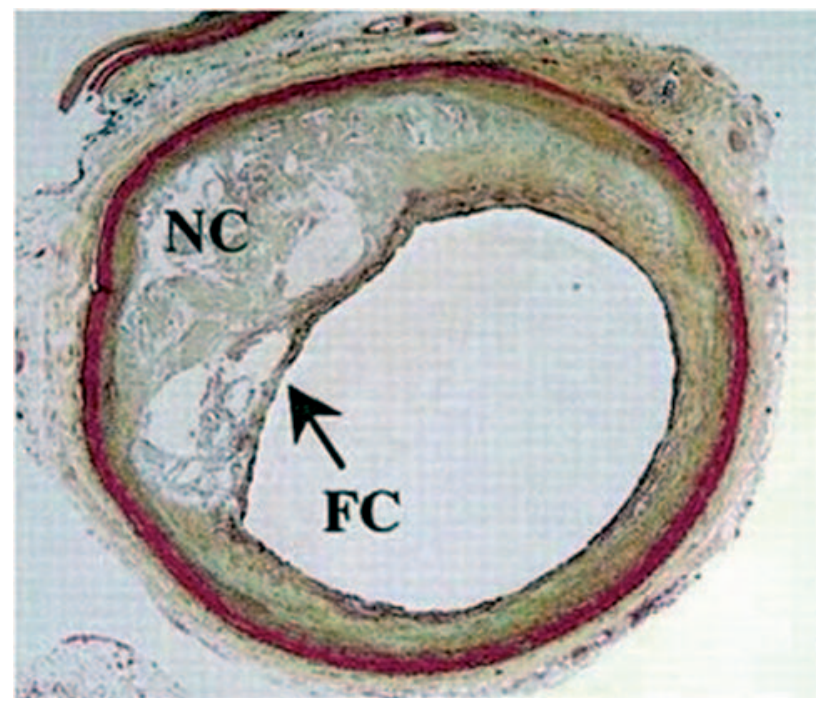

Figure 1. Thin-cap fibro atheroma (TCFA). TC indicates thin fibrous cap; NC, Large necrotic lipid core. ${ }^{6}$

(Reprinted with permission of Lippincott Williams \& Wilkins.)

proaches that use the adjacent venous circulation to bypass an obstructed artery and stent-based approach for ventricle to coronary artery bypass are being tested. Therapeutic angiogenesis and myogenesis are also being tested. Ongoing research on angiogenetic gene therapies and stem-cell transfer may result in additional therapeutic options benefiting patients with myocardial ischemia.

Despite the advances in the treatment of patients with coronary artery disease, sudden cardiac death is still prevalent. Sudden cardiac death occurs in half of all cardiac deaths and plaque rupture is the cause in more than $70 \%$ of such deaths. ${ }^{6,7}$ In addition, silent plaque rupture and its consequent wound healing accelerate plaque growth and is a more frequent feature in arteries with less severe luminal narrowing. ${ }^{8}$

It has been established that atherosclerotic plaque composition is a key determinant of the fate of such lesions. ${ }^{9}$ Lipid-rich necrotic cores occupying a large percentage of the plaque are considered highly thrombogenic and prone to rupture. ${ }^{9,10}$ In addition, high levels of free-cholesterol and cholesterol clefts are common features of ruptured plaques and its most prevalent predecessor, the thin-cap fibro atheroma (TCFA) (Figure 1).

A previous study of a large series of sudden death patients showed the presence of ruptured TCFA as the underlying cause of $60 \%$ of acute thrombi. Furthermore, $70 \%$ of those patients presented additional TCFAs without overlying rupture. ${ }^{12}$ Several novel invasive imaging techniques have been developed with the intention to identify one of more features of TCFA. ${ }^{13}$ Such techniques target the main characteris- tics of TCFA lesions: large lipid core, thin cap $(\leq 65$ $\mu \mathrm{m})$ and positive remodeling. Detection of these non-obstructive, lipid rich, high-risk plaques may potentially have an important impact in the prevention of acute myocardial infarction and sudden death.

\section{CATHETER-BASED CORONARY BYPASS \\ Percutaneous in Situ Coronary Venous Arterialization}

Catheter based coronary bypass has evolved since 1995. ${ }^{14,15}$ Percutaneous approaches that use the adjacent venous circulation to bypass an obstructed artery are being tested. In percutaneous in situ coronary venous arterialization (PICVA), a coronary artery is connected to the adjacent vein at one site upstream from the lesion, directing oxygenated blood flow into the vein (Figure 2). The oxygenated blood then travels through the venous system in the reverse direction to perfuse the myocardium. In a percutaneous in situ coronary artery bypass (PICAB), 2 channels are created between the coronary artery and the adjacent vein, one upstream and the other downstream from the lesion (Figure 3). The blood enters the upstream channel, flows through the isolated vein to bypass the lesion, and re-enters the healthy segments of the artery through the downstream channel. Oesterle et al reported the initial clinical experience with PICVA. ${ }^{15}$ PICVA was attempted in eleven patients with severe angina and no reasonable option for either angioplasty or surgical revascularization. In 6 patients, the adjacent vein could not be adequately targeted for successful needle and wire delivery. PICVA was successfully completed in 5 patients. Two of the 5 cases had catastrophic complications and died within $48 \mathrm{hr}$ of the procedure. Of the remaining 3 cases, all patients experienced an improvement in their anginal symptoms. However, 3-month follow-up angiography revealed a closed PICVA channel in 2 patients. After this initial clinical experience, the system of devices is currently undergoing significant modification (the new imaging strategy and modified connecting and blocking devices), and a further clinical study is underway.

\section{Stent-Based Approach for Ventricle to Coronary Artery Bypass}

Alternative approach, also performed via sternotomy, is a ventricle to coronary artery bypass (VCAB). In this procedure, a stent-based device (VSTENT) is used to create a conduit between the left ventricle and the left coronary artery, thereby increasing flow in the coronary artery. The advantage of this approach is that no grafting is necessary and it can be performed rapid- 

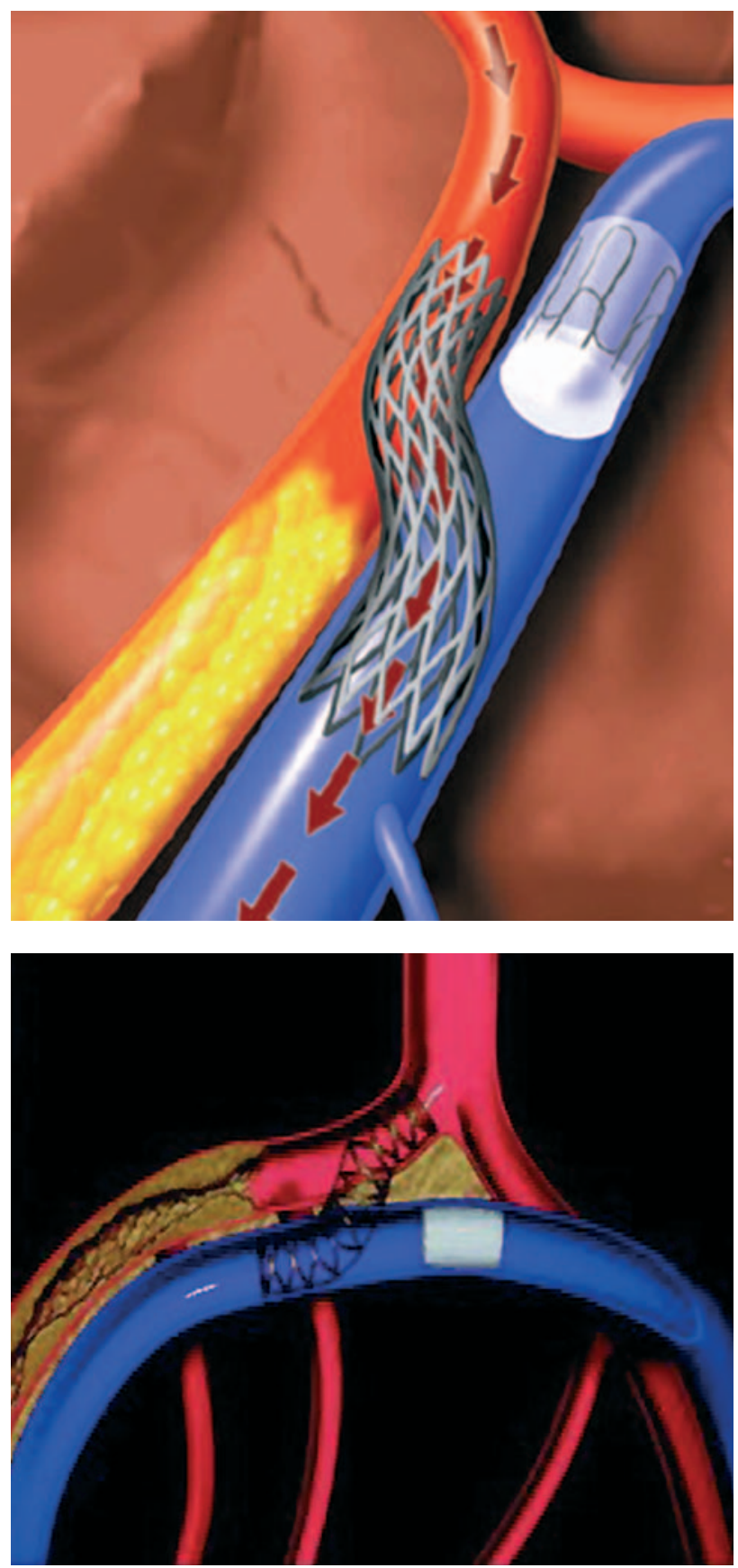

Figure 2. Percutaneous in situ coronary venous arterialization (PICVA). ${ }^{15}$

(Reprinted with permission of John Wiley \& Sons Ltd. All Rights Reserved.)

ly. Only one experimental revascularization procedure has been reported. ${ }^{16}$

\section{RETROGRADE PERFUSION}

Synchronized retroinfusion with arterial blood to coronary veins was able to partially reduce myocardial ischemia in patients undergoing percutaneous coronary angioplasty (PTCA).${ }^{17}$ In general, patients
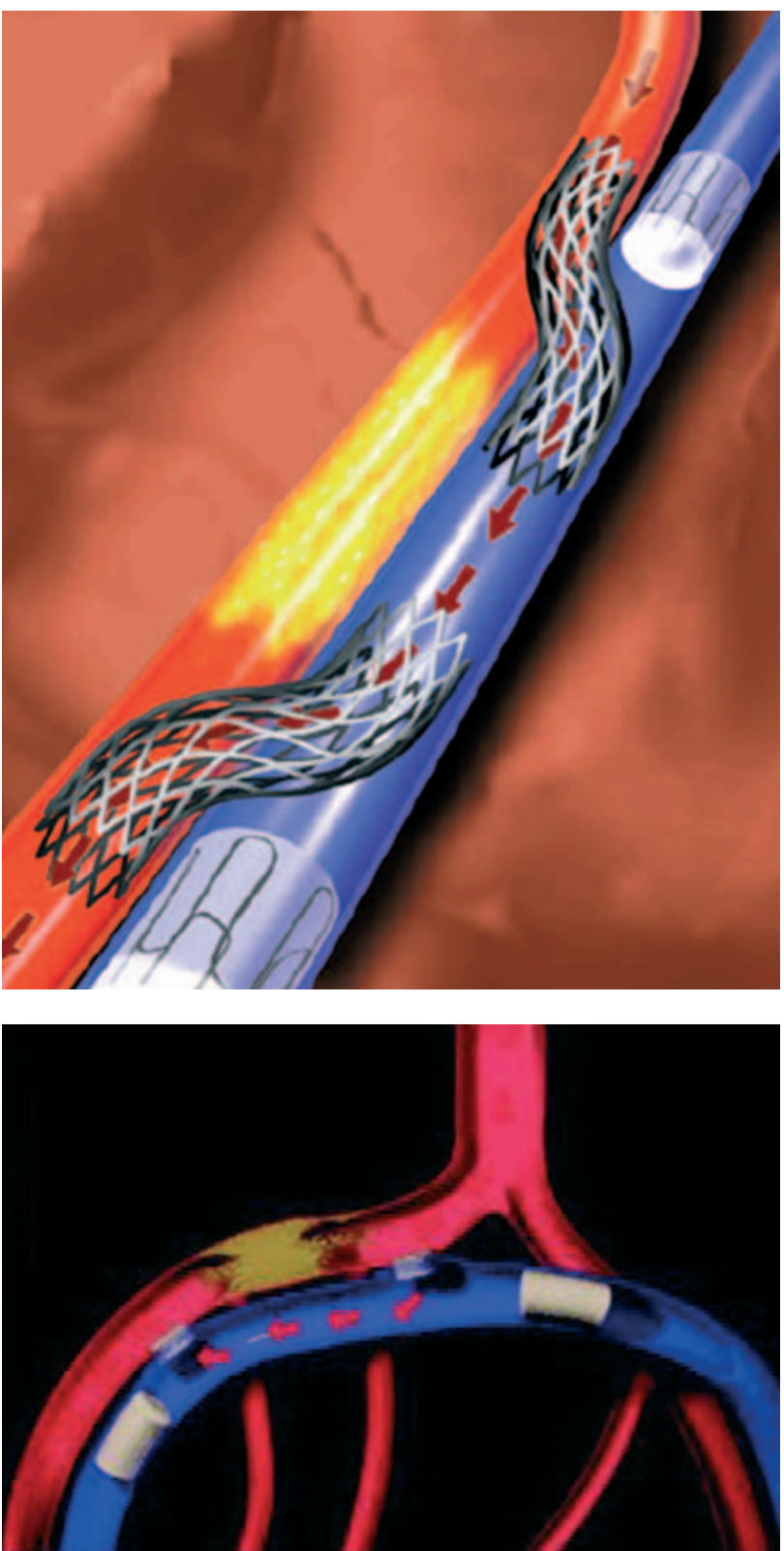

Figure 3. Percutaneous in situ coronary artery bypass (PICAB). ${ }^{15}$ (Reprinted with permission of John Wiley \& Sons Ltd. All Rights Reserved.)

with left main stenosis or left main-equivalent stenosis are considered to be at high risk for PTCA. Pohl et al reported on the 1-year results of a prospective randomized single center study (Myoprotect I) in 44 patients with symptomatic left main or left mainequivalent lesions, who were randomly assigned to the stent group $(n=23)$ or the bypass group $(n=21) .{ }^{18}$ In all patients randomized to percutaneous treatment, selective pressure-regulated retroperfusion of arterial blood into the anterior cardiac vein was applied during ischemia. Twenty-eight-day mortality and 1-year mortality rate as well as quality of life scores were 
Figure 4. Growth factors, cytokines, or hormones released endogeneously in response to tissue ischemia, or administered exogenously for therapeutic neovascularization, act to promote endothelia progenitor cell (EPC) proliferation, differentiation, and mobilization from bone marrow (via the peripheral circulation) to neovascular foci. ${ }^{19}$

(Reprinted with permission of Journal of Clinical Investigation.)

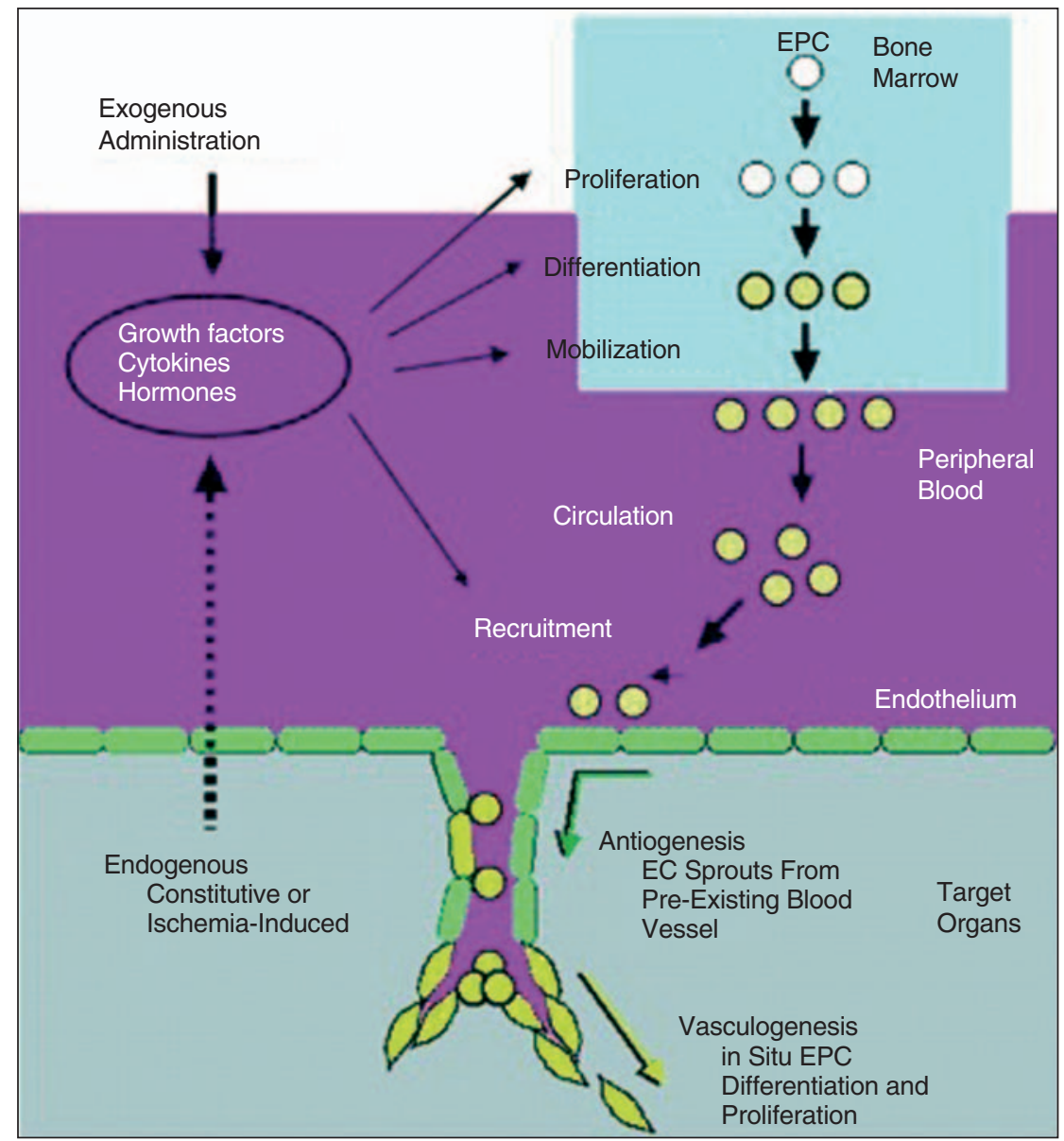

similar in both groups. Though event free survival was lower and target lesion revascularization rate was higher in the stent group, retroperfusion-supported stent implantation was associated with substantially lower costs and might be considered as an alternative treatment option in the selected group of high-risk patients.

\section{THERAPEUTIC ANGIOGENESIS AND VASCULOGENESIS}

Chronic imbalances of myocardial oxygen supply and demand produced by a coronary artery stenosis or occlusion have been shown to increase growth of the coronary collateral circulation. Angiogenesis and vasculogenesis are adaptive responses of the coronary collateral circulation to myocardial ischemia.

Therapeutic angiogenesis and vasculogenesis, which involves the administration of angiogenic growth factors, cytokines or stem cells to stimulate collateral formation and improve myocardial perfusion, is being tested as an alternative strategy for patients with medically intractable angina who are not candidates for mechanical revascularization therapies (Figure 4).

\section{Angiogenic Cytokines}

Preclinical studies have established a foundation for rational development of therapeutic angiogenesis. ${ }^{20-23}$ A variety of growth factors and chemokines convincingly increase the formation of small blood vessels in experimental models. Most clinical trials to date involve transfer of vascular endothelial growth factor (VEGF) or fibroblast growth factor (FGF) by several delivery strategies (Figure 5). ${ }^{24}$

\section{Protein Transfer}

With the advent of recombinant DNA technology, large quantities of purified proteins can be produced for therapeutic use (Table 1). ${ }^{25}$ Advantages of locally administering purified angiogenic factors include easy dose titration, repeat administration if necessary, and rapid metabolism to prevent toxicity. ${ }^{25}$ The primary disadvantages have been either a lack of efficacy in placebo-controlled studies or a need for administration during coronary artery bypass graft (CABG). Methods combining angiogenic proteins with slow-release systems are in development. 


\section{Gene Therapy}

Gene therapy is an approach in which the genetic material directing production of a protein is transferred in place of the protein itself. A number of vehicles are used for transferring DNA to heart tissue, including purified DNA, DNA/lipid complexes, adeno-associated viruses, or adenovirus..$^{24,25}$ An advantage of this approach appears to be localized, sustained but not indefinite production of angiogenic factors. ${ }^{26}$ Apparent disadvantages are the possibilities of vector toxicity, an immune response to the gene therapy vector, or inappropriately localized gene transfer resulting in angiogenesis in a tumour or the retina.

The efficacy of gene transfer approaches to therapeutic angiogenesis is now being tested in clinical trials (Table 2)..$^{25,27-33}$ Early uncontrolled open-label clinical trials generally gave positive results, although the possibility of a placebo effect was not excluded. Controlled Phase II trials are providing positive but not definitive results. This is promising, since the patient population being studied has failed all other therapies and is likely to be refractory to intervention. However, most of the efficacy measures studied to date are surrogate endpoints such as exercise tolerance time (ETT), angina, or perfusion. While these measures are useful in suggesting clinical efficacy, hard clinical endpoints such as mortality, myocardial infarction (MI) and the need for revascularization should be studied. Long-term follow up data are also necessary. An important observation is that the safety results of these trials indicate no major problems. Potential side-effects such as worsening of atherosclerosis, retinopathy or cancer, have not been observed in clinical trials.

Two large Phase III clinical trials (AGENT 3 and 4) were designed to evaluate further the safety and efficacy of Ad5FGF4. ${ }^{31}$ Both trials were designed as randomized, double blind and placebo controlled trials. In each trial, a recruitment goal was 450 patients and these patients would be randomized to 3 groups (placebo group, Ad5FGF-4 at a dose of $10^{9} \mathrm{vp}$ group, and Ad5FGF-4 at a dose of $10^{10} \mathrm{vp}$ group). In January 2004, enrollment was stopped (416 patients in AGENT 3 and 115 patients in AGENT 4) because interim data analysis of AGENT 3 indicates that the studies will provide insufficient evidence of efficacy. However, enrolled patients' follow-up continues and final data will be presented in the near future.

\section{Cell Based Therapy}

Another alternative method for increasing coronary vascularization is the transplantation of stem or progenitor cells. ${ }^{34,35}$ These cells not only produce a variety of growth factors and cytokines, but participate struc-

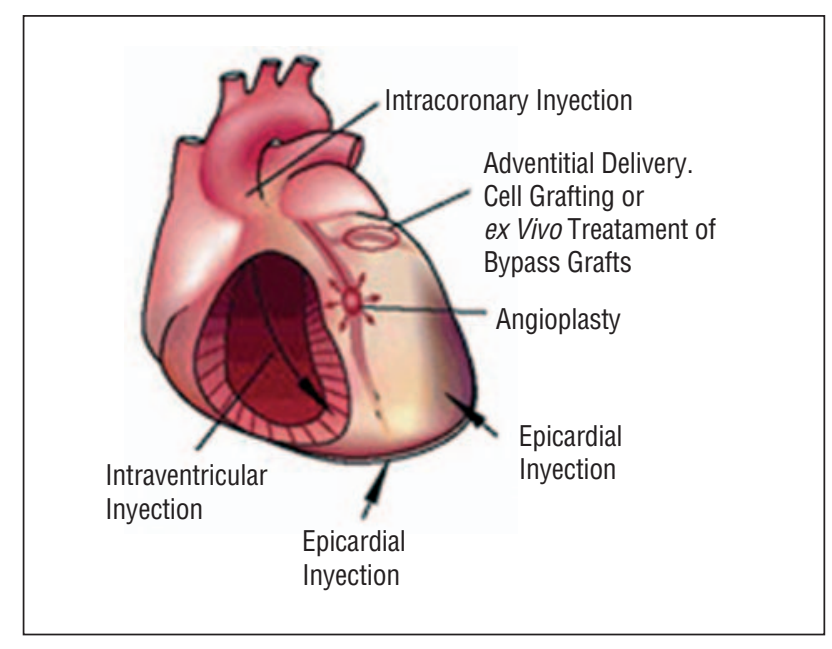

Figure 5. Clinical feasible gene delivery routes. ${ }^{25}$

(Reprinted with permission of Nature Publishing Group.)

turally in the formation of new vascular tissue and myocyte.

The promising results from experimental studies promoted the initiation of clinical trials. ${ }^{36,38}$ Stem and progenitor cells are being tested in patients with both acute myocardial infarction and chronic ischemic heart failure (Table 3 and 4)..$^{35,39-46}$ Improved wall motions or increased perfusion was demonstrated in most of study patients. However, BOOST is the sole randomized controlled clinical trial. ${ }^{42}$ Sixty patients with ST-segment elevation myocardial infarction

\section{TABLE 1. Proteins That Stimulate Angiogenesis in Preclinical Studies ${ }^{\star, 25}$}

\section{Growth factors}

VEGF-A, VEGF-B, VEGF-C, VEGF-D, VEGF-E, PLGF

FGF-1, FGF-2, FGF-4, FGF-5

Angiopoietin-1, Angiopoietin-2

HGF, PDGF-BB

GM-CSF, neurotropin

IGF-1, IGF-2

Chemokines

MCP-1

Transcription factors

HIF-1, Egr-1, Prox-1

Others

Del-1,Cyr 61, PR39

Tissue kallikrein, Secreted frizzled-related protein eNOS, iNOS

\footnotetext{
*VEGF indicates vascular endothelial growth factors. PLGF, placental growth factors; FGF, fibroblast growth factors; HGF, hepatocyte growth factors; PDGF, platelet derived growth factors; GM-CSF, granulocyte macrophage colony stimulating factors; IGF, insulin like growth factors; MCP, monocyte chemotactic protein; HIF, hypoxia inducible transcription factors; Egr-1, early growth response factor-1; Prox-1, prospero-related homeobox-1; Del-1, developmentally regulated endothelial cell locus-1; Cyr 61, cysteine-rich angiogenic inducer 61; PR 39, praline and arginine-rich peptide; eNOS, endothelial nitric oxide synthetase; iNOS, inducible nitric oxide synthetase.
} 
TABLE 2. The Result of Controlled Phase II Clinical Trials Testing Angiogenic Factors to Treat Coronary Heart Disease $e^{\star}, 25$

\begin{tabular}{|c|c|c|c|c|}
\hline Trial & Therapeutic Agent & No. & End Point & Results \\
\hline VIVA $^{27}$ & Recombinant VEGF protein & 178 & ETT (60 days) & Negative \\
\hline FIRST $^{28}$ & Recombinant FGF-2 protein & 337 & ETT (90 days) & Negative \\
\hline GM-CSF 29 & Recombinant GM-CSF protein & 21 & $\begin{array}{l}\text { Invasive collateral flow index } \\
\quad(2 \text { weeks })\end{array}$ & Positive \\
\hline AGENT $^{30}$ & Adenovirus-FGF-4 & 79 & ETT (4 weeks) & Positive \\
\hline AGENT II ${ }^{31}$ & Adenovirus-FGF-4 & 52 & MPI (8 weeks) & Positive \\
\hline $\mathrm{KAT}^{32}$ & $\begin{array}{l}\text { Adenovirus-VEGF } 165 \\
\text { Plasmid/liposome } \\
\text { VEGF165 (Adeno only) }\end{array}$ & 103 & MPI (6 months) & Positive \\
\hline Euroinject One ${ }^{33}$ & Plasmid VEGF165 & 74 & MPI (3 months) & Negative \\
\hline
\end{tabular}

*VEGF indicates vascular endothelial growth factors; FGF, fibroblast growth factors; ETT, exercise tolerance time; MPI, myocardial perfusion improvement.

were randomly assigned to either a control group that received optimum post infarction medical treatment, or a bone-marrow-cell group that received optimum medical treatment and intracoronary transfer of autologous bone marrow cells 4.8 days after percutaneous coronary intervention (PCI). After 6 months, mean global left ventricular ejection fraction (LVEF) had significantly increased in the bone-marrow-cell group, compared to the control group. However, most studies at present are limited by the small patient enrolment, and recently some papers reported that bone-marrow-derived haematopoietic stem cells do not transdifferentiate into cardiac myocytes in ischemic myocardium. ${ }^{47,48}$

\section{PERCUTANEOUS MYOBLAST TRANSPLANTATION}

Most preclinical experience has been reported on transplantation of skeletal myoblasts in infarcted myocardium. ${ }^{49-52}$ These studies demonstrated that transplanted skeletal myoblasts in damaged myocardium are capable of cellular engraftment, myotube forma- tion, and long-term graft survival. Several clinical percutaneous myoblast transplantation trials, using both the transendocardial and the transvenous approaches, have been reported.

\section{Transendocardial Approach}

A pilot safety and feasibility study on percutaneous transplantation of autologous skeletal myoblasts by transendocardial injection in five patients with ischemic heart failure was reported by the group of Rotterdam. ${ }^{50}$ Autologous skeletal myoblasts were obtained from the quadriceps muscle and cultured in vitro for cell expansion. With a $\mathrm{NOGA}^{\circledR}$-guided catheter system, $196 \pm 105$ million cells were transendocardially injected into the infarcted area. After 3 months, LV ejection fraction increased and regional wall analysis by magnetic resonance image (MRI) showed significant increased wall thickening at the target area. In the light of these preliminary favourable results, a multicenter European uncontrolled investigation has been started. Overall, 15 patients have been enrolled and treated with transendocardial skeletal myoblasts injection.

TABLE 3. Stem/Progenitor Cell Therapy (Intracoronary Application) in Patients With Acute Myocardial Infarction, 35

\begin{tabular}{|c|c|c|c|}
\hline Reference & Cell Type & Patients & Results \\
\hline Strauer et a $\left.\right|^{39}$ & BMC (40 mL) versus control & $n=10$ & $\begin{array}{l}\text { Hypokinetic area (LVA) } \downarrow \text {, contractility infarct } \\
\text { region } \uparrow \text {, end-systolic volume } \downarrow \text {, } \\
\text { perfusion (tallium scintigraphy) } \uparrow\end{array}$ \\
\hline TOPCARE-AMI ${ }^{40,41}$ & BMC $(50 \mathrm{~mL})$ versus $\mathrm{CPC}(250 \mathrm{~mL})$ & $n=20$ & $\begin{array}{l}\text { Global and regional EF (LVA, echo, MRI) } \uparrow \text {, } \\
\text { end-systolic volume, viability } \\
\text { (PET, MRI) } \uparrow \text {, coronary flow reserve } \uparrow\end{array}$ \\
\hline $\begin{array}{l}\text { BOOST (prospective } \\
\text { and randomised) }{ }^{42}\end{array}$ & BMC (120 mL) versus CONTROL & $n=30$ & $\mathrm{EF}(\mathrm{MRI}) \uparrow$ \\
\hline
\end{tabular}

*BMC indicates bone marrow cell; CPC, circulating progenitor cell; LVA, left ventricular angiogram; EF, ejection fraction; MRI, magnetic resonance image; PET, positron emission tomography. 
TABLE 4. Stem/Progenitor Cell Therapy in Patients With Chronic Heart Failure ${ }^{\star, 35}$

\begin{tabular}{|c|c|c|c|c|}
\hline Reference & Cell Type & Application & Patients & Results \\
\hline Stamm et al $\left.\right|^{43}$ & CD133+BMC (85-195 mL) & Injection during $\mathrm{CABG}$ & $n=6$ & $\begin{array}{l}\text { EF in } 4 \text { patients (LVA) } \uparrow \text {, perfusion } \\
\text { in } 5 \text { patients (SPECT) } \uparrow\end{array}$ \\
\hline Tse et al ${ }^{44}$ & BMC (50 mL) & Intramyocardial/NOGA & $\mathrm{n}=8$ & Wall motion and thickening $\uparrow$ \\
\hline Fuchs et $\mathrm{al}^{45}$ & BMC & Intramyocardial/NOGA & $n=10$ & $\begin{array}{l}\text { Angina score and stress-induced } \\
\text { ischemia improved }\end{array}$ \\
\hline Perin et ${ }^{46}$ & BMC (50 mL) & Intramyocardial/NOGA & $\mathrm{n}=14$ & $\mathrm{EF} \uparrow$, end-systolic volume $\downarrow$ \\
\hline
\end{tabular}

${ }^{*} \mathrm{CD}$ indicates cluster of differentiation; BMC, bone marrow cell; CABG, coronary artery bypass grafting; EF, ejection fraction; LVA, left ventricular angiogram; SPECT, single photon emission computed tomography; EF, ejection fraction.

The results of this study will be presented in the near future.

\section{Transvenous Approach}

A novel catheter-based endovascular system for direct myocardial injection using IVUS guide needle punctures via the coronary venous system (the TRANSAccess ${ }^{\mathrm{TM}}$ ) has been developed (Figure 6). ${ }^{53} \mathrm{In}$ the POZAN trial, 10 patients underwent intramyocardial injection by using the TRANSAccess. ${ }^{54}$ The procedure was not successful in one patient but NYHA class improved in all patients and ejection fraction increased 3\%-8\% in 6 out of 9 cases during 6 month follow-up.

\section{Ventricular Arrythmia}

After intramyocardial injection of skeletal myoblasts, ventricular arrhythmia was reported. Menasche et $\mathrm{a}^{52}$ reported that implantable cardioverter-defibrillator (ICD) implantation for ventricular arrythmias was required in 4 out of 10 patients after open chest autologus myoblast transplantation. ${ }^{50,52}$ One of the 5 patients who were enrolled in the study on percutaneous transplantation of autologous skeletal myoblasts by transendocardial approach had also sustained episodes of ventricular tachycardia and required ICD. This is probably related to: $a$ ) heterogenecity of action potentials between the native and the transplanted stem cells; b) intrinsic arrhythmia potential of injected cells; $c$ ) increased nerve sprouting induced by stem cell injection; and $d$ ) local injury or edema induced by myocardial puncture and inflammatory response.

\section{FUTURE PERSPECTIVES TOWARDS INVASIVE DETECTION OF VULNERABLE PLAQUE}

\section{Lipid-Rich Atheromatous Core}

IVUS provides an accurate tomographic view of the coronary arteries and has shown a high correlation with histology samples in in vitro validation studies. .5-57 $^{5}$ However, accurate plaque characterization with visual interpretation of gray-scale IVUS, particularly of lipid rich plaques, remains an unresolved issue..$^{56}$ On the contrary, spectral analysis of IVUS radiofrequency data (IVUS-Virtual Histology ${ }^{\mathrm{TM}}$ [IVUS-VH]) has demonstrated potential to provide detailed quantitative information on plaque composition and has been validated in studies of explanted human coronary segments (Figure 7) ${ }^{58}$

Angioscopic yellow plaques have been related to atheromatous plaques in previous validation studies. ${ }^{59}$ However, this technique evaluates only the luminal surface of the intima thus quantifiable values of lipid core size are out of its scope.

Raman spectroscopy is a technique that can characterize the chemical composition of tissues. ${ }^{60}$ In vitro studies have demonstrated that diagnostic algorithms allow the discrimination of coronary arterial tissue in 3 categories: non-atherosclerotic, non-calcified and calcified plaques. ${ }^{61}$ Nevertheless, this technique also lacks the ability to provide geometrical information of the vessel and has a shallow penetration depth.

Intravascular ultrasound elastography and palpography are techniques that allow the assessment of local mechanical tissue properties (Figure 8). ${ }^{62,63}$ At a defined pressure, soft tissue (lipid-rich) components will deform more than hard components (fibrous-calcified) ${ }^{64}$ However, they are unable to provide quantifiable measurements of plaque components.

Finally, intravascular magnetic resonance (IVMRI) has recently emerged as a potential tool to identify TCFA since it can accurately determine the presence of lipid within the arterial wall. ${ }^{65,66}$ In vivo feasibility remains to be proven and acquisition time and extent of the scan analysis requires improvement.

\section{Thin-Fibrous Cap}

The threshold to define the cap as "thin" has previously been set at $<65 \mu \mathrm{m} .{ }^{67}$ However, it is well 


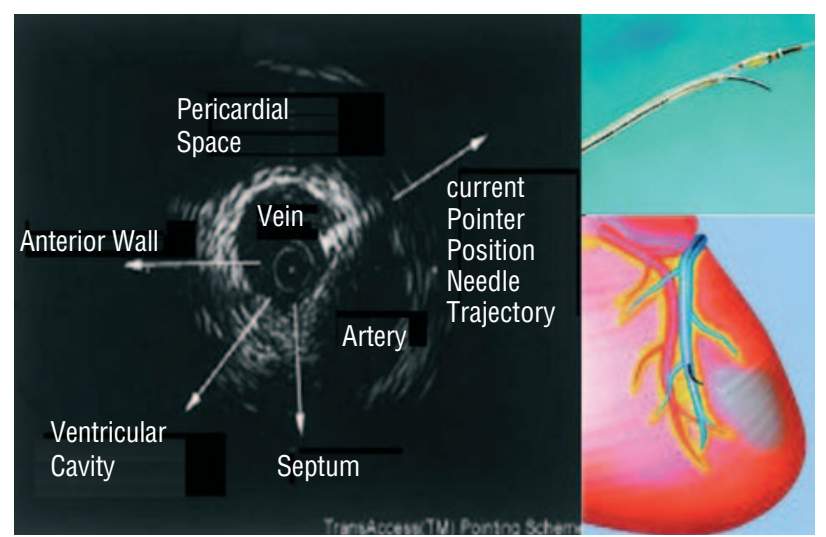

Figure 6. Direct myocardial injection using IVUS guide needle punctures via the coronary venous system.

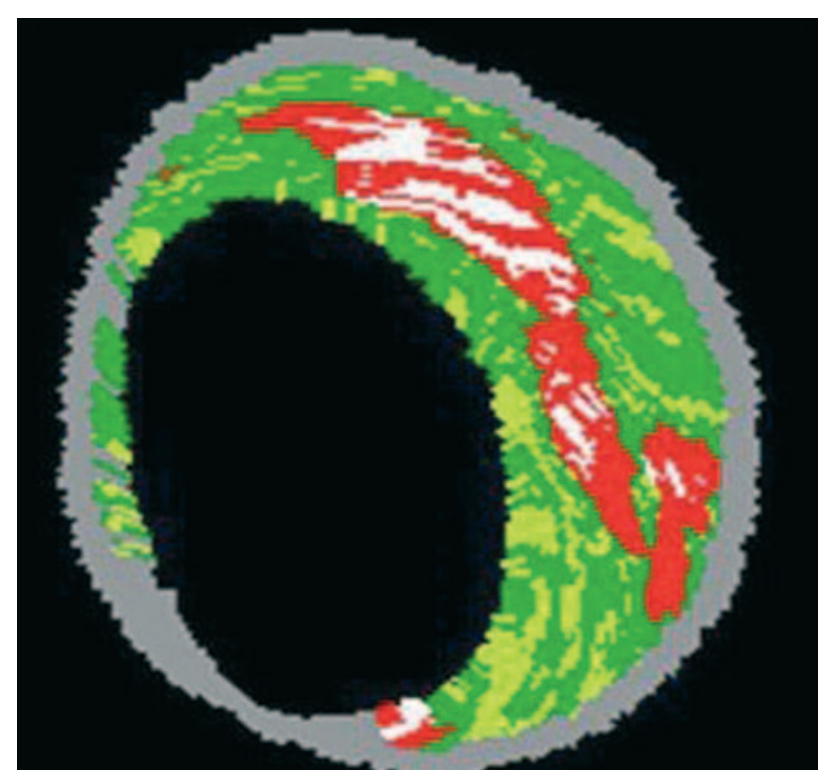

Figure 7. Virtual histology image. Red: lipid core. White: calcium. Yellow: fibrofatty. Green: fibrosis. Gray: media. established that general tissue shrinkage can not be avoided during dehydration. ${ }^{68}$ Shrinkage of up to $60 \%, 15 \%$ and $80 \%$ can occur during critical-pointdrying, free-drying, and air-drying respectively. ${ }^{69}$ Furthermore, post-mortem contraction of arteries further contributes to deteriorate the pathological quantification of atherosclerosis. ${ }^{70}$ Accordingly, we believe that the threshold should be higher than $65 \mu \mathrm{m}$. Since the axial resolution of IVUS is between 100 and $150 \mu \mathrm{m}$, techniques such as IVUS-VH with the capacity to quantify each plaque component and to identify the location of the lipid core in relation to the lumen have the potential to recognize all the 3 features of TCFA lesions.

Optical coherence tomography (OCT) is an imaging technique that allows high-resolution (axial resolution of $15 \mu \mathrm{m}$ ) imaging in biological systems (Figure 9). ${ }^{71}$ Accordingly, OCT has the capacity to allow in-vivo, real time visualization of a thin fibrous cap. Recent in vivo data suggest the possibility of detection of macrophages in atherosclerotic plaques. ${ }^{72}$

The sensitivity and specificity of palpography to detect vulnerable plaques has recently been assessed in post-mortem human coronary arteries where vulnerable plaques were detected with a sensitivity of $88 \%$ and a specificity of $89 \% .{ }^{63}$

\section{Positive Remodeling}

The expansive compensatory enlargement of the coronary arteries in response to an increase in plaque area is called positive or expansive remodeling. ${ }^{73}$ Several studies showed an increase in inflammatory marker levels, larger lipid cores, and pronounced medial thinning in positive remodeled vessels. ${ }^{74-76} \mathrm{Re}-$ cently, the relationship between vascular remodeling and plaque composition was assessed using IVUS. ${ }^{77-79}$ In these studies, the remodeling index for soft lesions
Figure 8. Palpography image. Yellow, high strain spot.

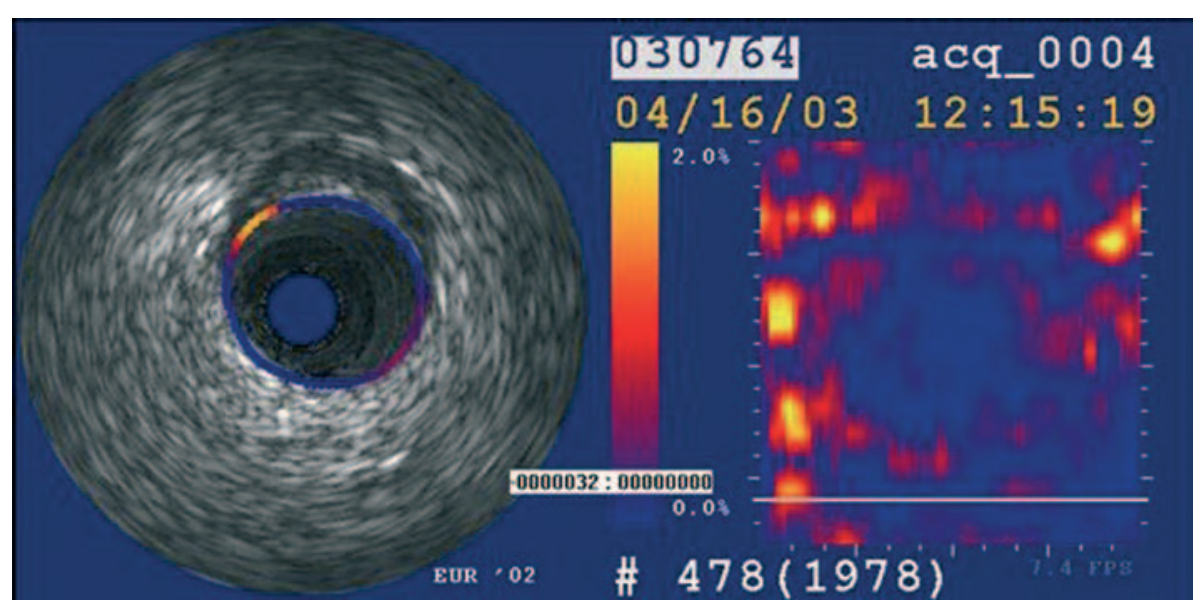

Rev Esp Cardiol. 2005;58(8):962-73 
was significantly higher than those for fibrous/mixed and calcified lesions. ${ }^{77-79}$ Aside from gray-scale IVUS, IVUS-VH can also accurately identify, as well as lipid core size and TCFA, the geometry of the vessel.

\section{Pan-Coronary Syndromes}

Several studies using angiography, IVUS, angioscopy, and palpography identified a high incidence of high-risk plaques throughout the coronary tree. ${ }^{80-83}$ In the study conducted by Rioufol et al, ${ }^{81}$ at least one plaque rupture was found away form the culprit lesion in $80 \%$ of the patients, away from the culprit artery in $71 \%$ and in the 2 non-culprit arteries in $12.5 \% .81$

Patients with acute myocardial infarction may present additional complex non-infarct-related coronary plaques. Furthermore, such multiple complex plaques have been found independent predictors of future clinical events. ${ }^{80}$

If the large number of high-risk plaques is detected throughout the coronary tree by means of angiography, angioscopy, IVUS, and palpography potential local preventive strategies could not be cost-effective. ${ }^{8,80-83}$ On the contrary, a systemic "plaque stabilization" approach including statins or angiotensin converting enzyme (ACE) inhibitors could be capable of "coolingdown" the inflammatory burden. ${ }^{84}$

\section{CONCLUSIONS}

Numerous percutaneous interventional treatments and diagnostic tools have been developed to diagnose the vulnerable plaque and to treat the large and increasing number of patients with myocardial ischemia. The proliferation of these strategies, and the need for multiple approaches in individual patients indicate that the problem of myocardial ischemia is not solved. Ongoing research on the use of drug eluting stents, catheter based bypass graft, therapeutic angiogenesis and myogenesis, and the catheter based devices to detect the plaque vulnerability and composition may result in additional diagnostic and therapeutic options for patients with coronary artery disease.

\section{REFERENCES}

1. Morice MC, Serruys PW, Sousa JE, Fajadet J, Ban Hayashi E, Perin $\mathrm{M}$, et al. A randomized comparison of a sirolimus-eluting stent with a standard stent for coronary revascularization. N Engl J Med. 2002;346:1773-80.

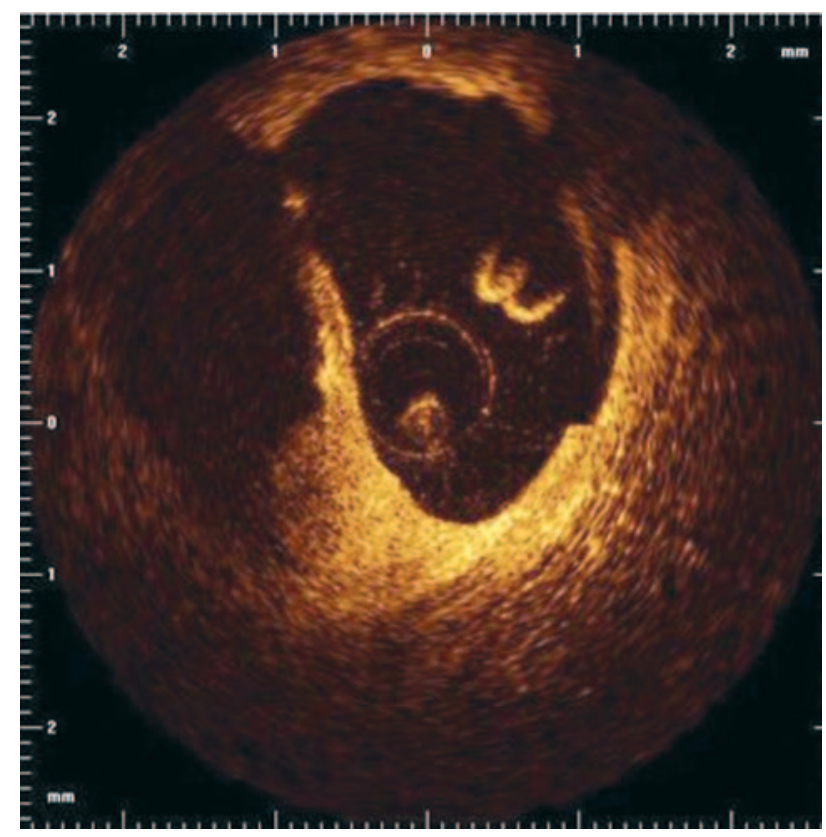

Figure 9. OCT image after plaque rupture.

2. Moses JW, Leon MB, Popma JJ, Fitzgerald PJ, Holmes DR, O'Shaughnessy C, et al. Sirolimus-eluting stents versus standard stents in patients with stenosis in a native coronary artery. N Engl J Med. 2003;349:1315-23.

3. Stone GW, Ellis SG, Cox DA, Hermiller J, O'Shaughnessy C, Mann JT, et al. A polymer-based, paclitaxel-eluting stent in patients with coronary artery disease. $\mathrm{N}$ Engl J Med. 2004;350:221-31.

4. Lemos PA, Serruys PW, van Domburg RT, Saia F, Arampatzis CA, Hoye A, et al. Unrestricted utilization of sirolimus-eluting stents compared with conventional bare stent implantation in the "real world": the Rapamycin-Eluting Stent Evaluated At Rotterdam Cardiology Hospital (RESEARCH) registry. Circulation. 2004;109:190-5.

5. McFadden EP, Stabile E, Regar E, Cheneau E, Ong AT, Kinnaird $\mathrm{T}$, et al. Late thrombosis in drug-eluting coronary stents after discontinuation of antiplatelet therapy. Lancet. 2004; 364:1519-21.

6. Virmani R, Kolodgie FD, Burke AP, Farb A, Schwartz SM. Lessons from sudden coronary death: a comprehensive morphological classification scheme for atherosclerotic lesions. Arterioscler Thromb Vasc Biol. 2000;20:1262-75.

7. Virmani R, Burke AP, Farb A. Sudden cardiac death. Cardiovasc Pathol. 2001;10:211-8.

8. Burke AP, Kolodgie FD, Farb A, Weber DK, Malcom GT, Smialek J, et al. Healed plaque ruptures and sudden coronary death: evidence that subclinical rupture has a role in plaque progression. Circulation. 2001;103:934-40.

9. Davies MJ, Richardson PD, Woolf N, Katz DR, Mann J. Risk of thrombosis in human atherosclerotic plaques: role of extracellular lipid, macrophage, and smooth muscle cell content. Br Heart J. 1993;69:377-81.

10. Gertz SD, Roberts WC. Hemodynamic shear force in rupture of coronary arterial atherosclerotic plaques. Am J Cardiol. 1990;66:1368-72.

11. Felton CV, Crook D, Davies MJ, Oliver MF. Relation of plaque lipid composition and morphology to the stability of human aortic plaques. Arterioscler Thromb Vasc Biol. $1997 ; 17: 1337-45$. 
12. Farb A, Burke AP, Tang AL, Liang TY, Mannan P, Smialek J, et al. Coronary plaque erosion without rupture into a lipid core. A frequent cause of coronary thrombosis in sudden coronary death. Circulation. 1996;93:1354-63.

13. Kolodgie FD, Burke AP, Farb A, Gold HK, Yuan J, Narula J, et al. The thin-cap fibroatheroma: a type of vulnerable plaque: the major precursor lesion to acute coronary syndromes. Curr Opin Cardiol. 2001;16:285-92.

14. Oesterle SN, Reifart N, Hauptmann E, Hayase M, Yeung AC. Percutaneous in situ coronary venous arterialization: report of the first human catheter-based coronary artery bypass. Circulation. 2001;103:2539-43.

15. Oesterle SN, Reifart N, Hayase M, Hauptmann E, Low R, Erbel R, et al. Catheter-based coronary bypass: a development update. Catheter Cardiovasc Interv. 2003;58:212-8.

16. Boekstegers P, Raake P, Al Ghobainy R, Horstkotte J, Hinkel $\mathrm{R}$, Sandner T, et al. Stent-based approach for ventricle-to-coronary artery bypass. Circulation. 2002;106:1000-6.

17. Boekstegers P, Giehrl W, von Degenfeld G, Steinbeck G. Selective suction and pressure-regulated retroinfusion: an effective and safe approach to retrograde protection against myocardial ischemia in patients undergoing normal and high risk percutaneous transluminal coronary angioplasty. J Am Coll Cardiol. 1998;31:1525-33.

18. Pohl T, Giehrl W, Reichart B, Kupatt C, Raake P, Paul S, et al. Retroinfusion-supported stenting in high-risk patients for percutaneous intervention and bypass surgery: results of the prospective randomized myoprotect I study. Catheter Cardiovasc Interv. 2004;62:323-30.

19. Isner JM, Asahara T. Angiogenesis and vasculogenesis as therapeutic strategies for postnatal neovascularization. J Clin Invest. 1999;103:1231-6.

20. Romano di Peppe S, Mangoni A, Zambruno G, Spinetti G, Melillo G, et al. Adenovirus-mediated $\operatorname{VEGF}(165)$ gene transfer enhances wound healing by promoting angiogenesis in CD1 diabetic mice. Gene Ther. 2002;9:1271-7.

21. Deodato B, Arsic N, Zentilin L, Galeano M, Santoro D, Torre $\mathrm{V}$, et al. Recombinant AAV vector encoding human VEGF165 enhances wound healing. Gene Ther. 2002;9:777-85.

22. Wright MJ, Wightman LM, Latchman DS, Marber MS. In vivo myocardial gene transfer: optimization and evaluation of intracoronary gene delivery in vivo. Gene Ther. 2001;8: 1833-9.

23. Vitadello M, Schiaffino MV, Picard A, Scarpa M, Schiaffino S. Gene transfer in regenerating muscle. Hum Gene Ther. 1994; 5:11-8.

24. Losordo DW, Dimmeler S. Therapeutic angiogenesis and vasculogenesis for ischemic disease. Part I: angiogenic cytokines. Circulation. 2004;109:2487-91.

25. Yla-Herttuala S, Alitalo K. Gene transfer as a tool to induce therapeutic vascular growth. Nat Med. 2003;9:694-701.

26. Simons M, Bonow RO, Chronos NA, Cohen DJ, Giordano FJ, Hammond HK, et al. Clinical trials in coronary angiogenesis: issues, problems, consensus: An expert panel summary. Circulation. 2000;102:E73-86.

27. Henry TD, Annex BH, McKendall GR, Azrin MA, López JJ, Giordano FJ, et al. The VIVA trial: Vascular endothelial growth factor in Ischemia for Vascular Angiogenesis. Circulation. 2003;107:1359-65.

28. Simons M, Annex BH, Laham RJ, Kleiman N, Henry T, Dauerman $\mathrm{H}$, et al. Pharmacological treatment of coronary artery disease with recombinant fibroblast growth factor-2: double-blind, randomized, controlled clinical trial. Circulation. 2002;105:788-93.

29. Seiler C, Pohl T, Wustmann K, Hutter D, Nicolet PA, Windecker $\mathrm{S}$, et al. Promotion of collateral growth by granulocyte-macrophage colony-stimulating factor in patients with coronary artery disease: a randomized, double-blind, placebo-controlled study. Circulation. 2001;104:2012-7.
30. Grines CL, Watkins MW, Helmer G, Penny W, Brinker J, Marmur JD, et al. Angiogenic Gene Therapy (AGENT) trial in patients with stable angina pectoris. Circulation. 2002;105:1291-7.

31. Grines C. The AGENT clinical trials programme. Eur Heart J Supplement. 2004;6:18-23.

32. Hedman M, Hartikainen J, Syvanne M, Stjernvall J, Hedman A, Kivela A, et al. Safety and feasibility of catheter-based local intracoronary vascular endothelial growth factor gene transfer in the prevention of postangioplasty and in-stent restenosis and in the treatment of chronic myocardial ischemia: phase II results of the Kuopio Angiogenesis Trial (KAT). Circulation. 2003; 107:2677-83.

33. Kastrup J. Euroinject One trial. Late breaking clinical trials session. J Am Coll Cardiol. 2003;41:1603.

34. Rafii S, Lyden D. Therapeutic stem and progenitor cell transplantation for organ vascularization and regeneration. Nat Med. 2003;9:702-12.

35. Losordo DW, Dimmeler S. Therapeutic angiogenesis and vasculogenesis for ischemic disease: part II: cell-based therapies. Circulation. 2004;109:2692-7.

36. Kawamoto A, Gwon HC, Iwaguro H, Yamaguchi JI, Uchida S, Masuda $\mathrm{H}$, et al. Therapeutic potential of ex vivo expanded endothelial progenitor cells for myocardial ischemia. Circulation. 2001;103:634-7.

37. Fuchs S, Baffour R, Zhou YF, Shou M, Pierre A, Tio FO, et al. Transendocardial delivery of autologous bone marrow enhances collateral perfusion and regional function in pigs with chronic experimental myocardial ischemia. J Am Coll Cardiol. 2001;37:1726-32.

38. Kawamoto A, Tkebuchava T, Yamaguchi J, Nishimura H, Yoon YS, Milliken C, et al. Intramyocardial transplantation of autologous endothelial progenitor cells for therapeutic neovascularization of myocardial ischemia. Circulation. 2003;107: 461-8.

39. Strauer BE, Brehm M, Zeus T, Kostering M, Hernandez A, Sorg RV, et al. Repair of infarcted myocardium by autologous intracoronary mononuclear bone marrow cell transplantation in humans. Circulation. 2002;106:1913-8.

40. Assmus B, Schachinger V, Teupe C, Britten M, Lehmann R, Dobert N, et al. Transplantation of Progenitor Cells and Regeneration Enhancement in Acute Myocardial Infarction (TOPCARE-AMI). Circulation. 2002;106:3009-17.

41. Britten MB, Abolmaali ND, Assmus B, Lehmann R, Honold J, Schmitt J, et al. Infarct remodeling after intracoronary progenitor cell treatment in patients with acute myocardial infarction (TOPCARE-AMI): mechanistic insights from serial contrastenhanced magnetic resonance imaging. Circulation. 2003;108: 2212-8.

42. Wollert KC, Meyer GP, Lotz J, Ringes-Lichtenberg S, Lippolt $\mathrm{P}$, Breidenbach $\mathrm{C}$, et al. Intracoronary autologous bonemarrow cell transfer after myocardial infarction: the BOOST randomised controlled clinical trial. Lancet. 2004;364:1418.

43. Stamm C, Westphal B, Kleine HD, Petzsch M, Kittner C, Klinge $\mathrm{H}$, et al. Autologous bone-marrow stem-cell transplantation for myocardial regeneration. Lancet. 2003;361:45-6.

44. Tse HF, Kwong YL, Chan JK, Lo G, Ho CL, Lau CP. Angiogenesis in ischaemic myocardium by intramyocardial autologous bone marrow mononuclear cell implantation. Lancet. 2003;361:47-9.

45. Fuchs S, Satler LF, Kornowski R, Okubagzi P, Weisz G, Baffour R, et al. Catheter-based autologous bone marrow myocardial injection in no-option patients with advanced coronary artery disease: a feasibility study. J Am Coll Cardiol. 2003;41: 1721-4.

46. Perin EC, Dohmann HF, Borojevic R, Silva SA, Sousa AL, Mesquita CT, et al. Transendocardial, autologous bone marrow cell transplantation for severe, chronic ischemic heart failure. Circulation. 2003;107:2294-302. 
47. Balsam LB, Wagers AJ, Christensen JL, Kofidis T, Weissman IL, Robbins RC. Haematopoietic stem cells adopt mature haematopoietic fates in ischaemic myocardium. Nature. 2004;428: 668-73.

48. Murry CE, Soonpaa MH, Reinecke H, Nakajima H, Nakajima HO, Rubart M, et al. Haematopoietic stem cells do not transdifferentiate into cardiac myocytes in myocardial infarcts. Nature. 2004;428:664-8.

49. Herreros J, Prosper F, Pérez A, Gavira JJ, García-Velloso MJ, Barba J, et al. Autologous intramyocardial injection of cultured skeletal muscle-derived stem cells in patients with non-acute myocardial infarction. Eur Heart J. 2003;24:201220.

50. Smits PC, van Geuns RJ, Poldermans D, Bountioukos M, Onderwater $\mathrm{EE}$, Lee $\mathrm{CH}$, et al. Catheter-based intramyocardial injection of autologous skeletal myoblasts as a primary treatment of ischemic heart failure: clinical experience with six-month follow-up. J Am Coll Cardiol. 2003;42:2063-9.

51. Menasche P, Hagege AA, Scorsin M, Pouzet B, Desnos M, Duboc D, et al. Myoblast transplantation for heart failure. Lancet. 2001;357:279-80.

52. Menasche P, Hagege AA, Vilquin JT, Desnos M, Abergel E, Pouzet B, et al. Autologous skeletal myoblast transplantation for severe postinfarction left ventricular dysfunction. J Am Coll Cardiol. 2003;41:1078-83.

53. Thompson CA, Nasseri BA, Makower J, Houser S, McGarry M, Lamson T, et al. Percutaneous transvenous cellular cardiomyoplasty. A novel nonsurgical approach for myocardial cell transplantation. J Am Coll Cardiol. 2003;41:1964-71.

54. Siminiak T, Fiszer D, Jerzykowska O, Rozwadowska N, Grygielska B, Majewski M, et al. Percutaneous transvenous transplantation of autologus myoblasts in the treatment of postinfarction heart failure-the Pozan trial. Eur Heart J. 2004;25: 264.

55. Tobis JM, Mallery JA, Gessert J, Griffith J, Mahon D, Bessen $\mathrm{M}$, et al. Intravascular ultrasound cross-sectional arterial imaging before and after balloon angioplasty in vitro. Circulation. 1989;80:873-82.

56. Potkin BN, Bartorelli AL, Gessert JM, Neville RF, Almagor Y, Roberts WC, et al. Coronary artery imaging with intravascular high-frequency ultrasound. Circulation. 1990;81:1575-85.

57. Nishimura RA, Edwards WD, Warnes CA, Reeder GS, Holmes DR Jr, Tajik AJ, et al. Intravascular ultrasound imaging: in vitro validation and pathologic correlation. J Am Coll Cardiol. 1990;16:145-54.

58. Nair A, Kuban BD, Tuzcu EM, Schoenhagen P, Nissen SE, Vince DG. Coronary plaque classification with intravascular ultrasound radiofrequency data analysis. Circulation. 2002;106: 2200-6.

59. Thieme T, Wernecke KD, Meyer R, Brandenstein E, Habedank D, Hinz A, et al. Angioscopic evaluation of atherosclerotic plaques: validation by histomorphologic analysis and association with stable and unstable coronary syndromes. J Am Coll Cardiol. 1996;28:1-6.

60. Baraga JJ, Feld MS, Rava RP. In situ optical histochemistry of human artery using near infrared Fourier transform Raman spectroscopy. Proc Natl Acad Sci U S A. 1992;89: 3473-7.

61. Romer TJ, Brennan JF 3rd, Fitzmaurice M, Feldstein ML, Deinum G, Myles JL, et al. Histopathology of human coronary atherosclerosis by quantifying its chemical composition with Raman spectroscopy. Circulation. 1998;97:878-85.

62. Schaar JA, Regar E, Mastik F, McFadden EP, Saia F, Disco C, et al. Incidence of high-strain patterns in human coronary arteries: assessment with three-dimensional intravascular palpography and correlation with clinical presentation. Circulation. 2004;109:2716-9.

63. Schaar JA, de Korte CL, Mastik F, Strijder C, Pasterkamp G, Boersma E, et al. Characterizing vulnerable plaque features with intravascular elastography. Circulation. 2003;108:263641.

64. de Korte CL, van der Steen AF, Cespedes EI, Pasterkamp G. Intravascular ultrasound elastography in human arteries: initial experience in vitro. Ultrasound Med Biol. 1998;24:4018.

65. Schneiderman JWR, Weiss A, Smouha E, Muchnik L, ChenZion M, Golan E, et al. Detection of vulnerable plaques in exvivo human aortas with novel intravascular magnetic resonance catheter(abstract). Circulation. 2002;657.

66. Schneiderman JWR, Weiss A, Smouha E, Muchnik L, Alexandrowicz G, Chen-Zion M, et al. Vulnerable plaque diagnosis by a self-contained intravascular magnetic resonance imaging probe in ex-vivo human in-situ coronary arteries. J Am Coll Cardiol. 2003;41:59A.

67. Burke AP, Farb A, Malcom GT, Liang YH, Smialek J, Virmani $\mathrm{R}$. Coronary risk factors and plaque morphology in men with coronary disease who died suddenly. N Engl J Med. 1997;3 $36: 1276-82$.

68. MKW L. A critical appraise of the effects of fixation, dehydration and embedding of cell volume. In: Revel JP, Barnard T, Haggis GH, editors. The Science of Biological Specimen Preparation for Microscopy and Microanalysis. Scanning Electron Microscopy, AMF O'Hare, IL 60666 1984; pp.6170.

69. Boyde A JS, Tamarin A. Dimensional changes during specimen preparation for scanning electron microscopy. Scan Electron Microsc. 1977:507-18.

70. Fishbein MC, Siegel RJ. How big are coronary atherosclerotic plaques that rupture? Circulation. 1996;94:2662-6.

71. Hrynchak P, Simpson T. Optical coherence tomography: an introduction to the technique and its use. Optom Vis Sci. 2000;77:347-56.

72. MacNeill BD, Jang IK, Bouma BE, Iftimia N, Takano M, Yabushita $\mathrm{H}$, et al. Focal and multi-focal plaque macrophage distributions in patients with acute and stable presentations of coronary artery disease. J Am Coll Cardiol. 2004;44:972-9.

73. Glagov S, Weisenberg E, Zarins CK, Stankunavicius R, Kolettis GJ. Compensatory enlargement of human atherosclerotic coronary arteries. N Engl J Med. 1987;316:1371-5.

74. Pasterkamp G, Schoneveld AH, van der Wal AC, Haudenschild CC, Clarijs RJ, Becker AE, et al. Relation of arterial geometry to luminal narrowing and histologic markers for plaque vulnerability: the remodeling paradox. J Am Coll Cardiol. 1998;32:655-62.

75. Varnava AM, Mills PG, Davies MJ. Relationship between coronary artery remodeling and plaque vulnerability. Circulation. 2002;105:939-43.

76. Burke AP, Kolodgie FD, Farb A, Weber D, Virmani R. Morphological predictors of arterial remodeling in coronary atherosclerosis. Circulation. 2002;105:297-303.

77. Tauth J, Pinnow E, Sullebarger JT, Basta L, Gursoy S, Lindsay $\mathrm{J} \mathrm{Jr}$, et al. Predictors of coronary arterial remodeling patterns in patients with myocardial ischemia. Am J Cardiol. 1997;80: 1352-5.

78. Sabate M, Kay IP, de Feyter PJ, van Domburg RT, Deshpande NV, Ligthart JM, et al. Remodeling of atherosclerotic coronary arteries varies in relation to location and composition of plaque. Am J Cardiol. 1999;84:135-40.

79. Fuessl RT, Kranenberg E, Kiausch U, Baer FM, Sechtem U, Hopp HW. Vascular remodeling in atherosclerotic coronary arteries is affected by plaque composition. Coron Artery Dis. 2001;12:91-7.

80. Goldstein JA, Demetriou D, Grines CL, Pica M, Shoukfeh M, O'Neill WW. Multiple complex coronary plaques in patients with acute myocardial infarction. N Engl J Med. 2000;343:91522.

81. Rioufol G, Finet G, Ginon I, Andre-Fouet X, Rossi R, Vialle E, et al. Multiple atherosclerotic plaque rupture in acute coronary 
syndrome: a three-vessel intravascular ultrasound study. Circulation. 2002;106:804-8.

82. Asakura M, Ueda Y, Yamaguchi O, Adachi T, Hirayama A, Hori M, et al. Extensive development of vulnerable plaques as a pan-coronary process in patients with myocardial infarction: an angioscopic study. J Am Coll Cardiol. 2001;37: 1284-8.
83. Schaar JA, Muller JE, Falk E, Virmani R, Fuster V, Serruys $\mathrm{PW}$, et al. Terminology for high-risk and vulnerable coronary artery plaques. Report of a meeting on the vulnerable plaque, June 17 and 18, 2003, Santorini, Greece. Eur Heart J. 2004;25:1077-82.

84. Ambrose JA, Martínez EE. A new paradigm for plaque stabilization. Circulation. 2002;105:2000-4. 